\title{
Accumulation of Heavy Metals by Soil and Agricultural Plants in the Zone of Technogenic Impact
}

\author{
D.V. Vinogradov ${ }^{1}$, T.V. Zubkova ${ }^{2}$
}

10.18805/IJARe.A-651

\begin{abstract}
Background: The transformation of natural elements, the migration of soil substances used in industry most often refer to metals, as a result of which "metallization" of landscapes occurs in industrial regions.

Methods: The article proposes an analysis of studies, conducting agroecological monitoring of soil and plants in the zone affected by the action of Ryazan power plant in 2015-2019. Experiments included the analysis of the soil and climatic conditions of the area, sampling in the zone of five rings of the pipe of the polluting enterprise, the analysis of the content of some trace elements in the coal during combustion and the products of their combustion, as well as heavy metals in the biomass of the main types of plant communities in the zone of influence and mobile forms of metals in the soil of the zone, depending on the main directions of influence.

Result: According to the results, the greatest distribution of mobile forms of heavy metals in the impact zone of Ryazan State District Power Plant (RGRES) was observed in the southern and southeastern directions in radii from $2.5 \mathrm{~km}$ to $30 \mathrm{~km}$, in the southwest direction it was in radii from $500 \mathrm{~m}$ to $7 \mathrm{~km}$ and in the northern and northwestern directions it was within a radius of $500 \mathrm{~m}$ to $2.5 \mathrm{~km}$ from the station.
\end{abstract}

Key words: Agrocoenosis, Heavy metals, Plant, Power plant, Pollutants, Soil, Technogenic impact.

\section{INTRODUCTION}

The soil is the natural resource, the efficiency of which largely determines the economic, social and environmental situation in the country, the well-being of each person. Soil is a nonrenewable or finite resource and is the bank of nutrients for plant growth (Aleminew et al., 2020).

Recently, a high anthropogenic load has acquired a large scale on the environment of agricultural territories in individual regions of the country, which includes Ryazan region. The basis for agriculture is soil (Gulidova et al., 2017; Butov et al., 2019; Bhabesh, 2011). It contains all the necessary components for growing crops in order to implement the country's food security (Vinogradov et al., 2018; Zubkova et al., 2020).

It should be noted that reclamation measures should be carried out at any levels of pollution, firstly, in order to prevent further pollutants from entering the soil; secondly, to clean the soil from existing pollutants; and, thirdly, to prevent the accumulation of the latter in crop and livestock products. To clean the soil from heavy metals and other pollutants, methods based on the extraction of the contaminated layer, which is subjected to further extraction or thermal treatment, are often used (especially at a high level of pollution) (Vinogradov et al., 2018; Shchur, 2017).

Soil is a very important component of our planet, it is in the soil that all biogeochemical cycles are closed. It acts as a connecting link in many vital processes of plants, animals, bacteria and fungi (Gregorich et al., 1997; Rillig and Mummey, 2006; Lambers et al. 2009).

The soil has a sanitary and informational function (Otterpohl et al., 1999). Due to the biota living in the soil, it can self-purify from various toxicants and heavy metals that
${ }^{1}$ Faculty of Technology, Department of Agronomy and Agricultural Technologies, Ryazan State Agrotechnological University Named after P.A. Kostychev, 1 Kostycheva Str., Ryazan, Ryazan region, 390044, Russian Federation.

${ }^{2}$ Agro-industrial Institute, Department of Technology of Storage and Processing of Agricultural Products, Bunin Yelets State University, 28 Kommunarov str., Yelets, Lipetsk Region, 399770, Russian Federation.

Corresponding Author: D.V. Vinogradov, Faculty of Technology, Department of Agronomy and Agricultural Technologies, Ryazan State Agrotechnological University Named after P.A. Kostychev, 1 Kostycheva Str., Ryazan, Ryazan region, 390044, Russian Federation. Email: vdvrzn@mail.ru

How to cite this article: Vinogradov, D.V. and Zubkova, T.V. (2021). Accumulation of Heavy Metals by Soil and Agricultural Plants in the Zone of Technogenic Impact. Indian Journal of Agricultural Research. DOI: 10.18805/IJARe.A-651.

Submitted: 08-05-2021 Accepted: 03-08-2021 Online: 06-09-2021

have a negative effect on soil fertility (Díaz Zorita et al., 2002; Dias et al., 2015).

One of the unique properties of soil is "memory", that is, the ability to store long-term information about the ecological state of the territory (Marfenina et al., 2008; Targulian and Bronnikova, 2019). This is very important for the organization of monitoring, on the basis of which it is possible to predict changes in the ecological properties of the soil in the process of human activity (Pavao Zuckerman, 2008; Vos et al., 2000; Vinogradov et al., 2021).

In recent years, human activity has transformed into a leading environmental factor in terms of the importance of 
impact on agricultural lands (Grimm et al., 2000; Vinogradov et al., 2020; Musayev et al., 2020).

The transformation of natural elements, the migration of soil substances used in industry most often refer to metals, as a result of which "metallization" of landscapes occurs in industrial regions (Ivanisova et al., 2019). As a result, the chemical composition of crop production changes, as well as various natural processes of migration of chemical elements (Vinogradov et al., 2018; Vinogradov et al., 2019). In order to identify changes in due time, assess, predict, prevent and eliminate the consequences of negative processes occurring in the soil in the zone of action of manmade objects, agroecological monitoring of lands is required (Navneet, 2014). One of these facilities in Ryazan region is Ryazan State District Power Plant (RGRES).

The scientific novelty of the research consisted in the development of methodological support and assessment, allowing to determine changes, forecast, prevention and elimination of the consequences of negative processes occurring in the soil in the zone of technogenic objects in the form of agroecological monitoring of lands.

The purpose of the study was to organize and conduct agroecological monitoring in the area of operation of Ryazan State District Power Plant.

Thus, it is necessary to make certain changes in technological processes in industry and improve agricultural technologies in order to reduce the anthropogenic load on the landscape, which in our opinion is a very relevant area of research.

In accordance with this goal, we will highlight the following tasks:

- Study the purpose and structure of agro-environmental monitoring.

- Analyze the environmental and technical characteristics of the subject of the study.

- Agroecological monitoring in the area of the GRES.

- Analyse the results.

- Develop environmental measures aimed at reducing the content of heavy metals in soils.

- Determine the amount of damage caused by land pollution.

The scientific innovation consists in the development of methodological support and assessment, which make it possible to determine changes, forecast, prevention and elimination of the consequences of negative processes occurring in the soil in the area of man-made objects as agroecological land mining. The results of the studies can serve as a basis and complement in the field of environmental monitoring, agriculture, resource conservation, nature management and environmental protection.

The common system of agroecological monitoring allows us to focus the efforts of different environmental organizations and not only for the purpose of joint work in the field of assessment and protection of various elements of agroecosystems. It is thanks to this that it is possible to develop a sufficiently objective system that can be applied to solve various problems (Vinogradov et al., 2020; Musayev et al., 2020).

Therefore, when considering the agricultural landscape as an integral, natural and agricultural territory, it is imperative to pay attention to the study and determination of the level of soil contamination with heavy metals.

\section{MATERIALS AND METHODS}

The object of the research was soil and agrocenoses in the zone of RGRES. Ryazan GRES is located in Pronsky district of Ryazan region (Russian Federation), $80 \mathrm{~km}$ southeast of the city of Ryazan and $1 \mathrm{~km}$ east of the city of Novomichurinsk, within a radius of $15-20 \mathrm{~km}$ from the monitored lands belonging to agricultural enterprise Plamya LLC, the village of Amanovo, Korablinsky district. Coordinates: 54.03556 ${ }^{\circ}$ north latitude and $39.77944^{\circ}$ east longitude. The research was conducted during 2015-2019 on the basis of the Ryazan State Technological University Named after P. A. Kostychev. Agroecological monitoring was carried out in order to study (survey) the influence of RGRES on edaphic and phytogenic factors in the nearest territory within a radius of $30 \mathrm{~km}$.

RGRES develops a capacity of $2,800 \mathrm{MW}$, while according to the project, the maximum permissible capacity is 3,600 MW. Ryazan GRES is the sixth in the list of the most powerful thermal power plants of the Russian Federation.

The studies were carried out on the territory located in the center of the Russian Plain, in the central and western parts of Ryazan region. This area is located on the border of the Pronsko-Don and Pronsko-Ryazan salient of the Central Russian Upland and Ranovo-Pronsky and NizhnePronsky blocks of the Oka-Don plain. Consequently, the impact zone of GRES belongs to two macro-morpho structures of the Russian Plain.

Chernozems, common in the zone of influence of RGRES, are, as a rule, heavy loamy (the content of physical clay in the arable layer is $45-50 \%$ and that of silt is 20 $30 \%$ ). The humus content in them is $6-7 \%$, the thickness of $\mathrm{A}+\mathrm{AB}$ horizon is $40-80 \mathrm{~cm}$. Soils with $\mathrm{pH}$ of $5-6$ prevail, having on average 5.4. The soils are well structured, have a granular and powdery-granular structure. The density of the humus horizon is about $1.1 \mathrm{~g} / \mathrm{cm}^{3}$ and increases insignificantly with depth. The eluvial horizon is not pronounced, the boiling depth is about $1 \mathrm{~m}$. On the slopes of interfluves, especially convex ones, there are washedout leached chernozems with a humus horizon less than 40 $\mathrm{cm}$ thick Shchur (2017).

During soil-geochemical studies, soil samples were taken from a depth of up to $20 \mathrm{~cm}$. These samples consisted of elementary samples of 6-10 pieces. Sampling was carried out in accordance with the requirements of GOST and methodological guidelines, from the end of April to the end of July. Vegetation sampling was timed to stationary points of soil sampling. Mixed samples of phyto cenotic mass also composed of 6-10 individual samples had the ratio of species typical for this community. 
The samples were dried to an air-dry state, crushed and analyzed for the content of bulk forms of heavy metals. In this case, the samples were analyzed separately from each other.

Sampling was carried out at stationary points located around the power plant, using "azimuthal" method. The essence of this method lies in the use of geodetic instruments to lay out sections in sixteen directions of light. This sampling was carried out along the sections in the following radii: $500 \mathrm{~m}, 2.5 \mathrm{~km}, 7 \mathrm{~km}, 15 \mathrm{~km}, 30 \mathrm{~km}$.

In soil and plant samples, the total content of heavy metals was determined by the atomic adsorption method (plasma version) according to the CINAO method using $\mathrm{HNO}_{3}$ as an estrogen. And in a number of soil samples, mobile forms of heavy metals were determined, both occluded and exchangeable ones (extractants, respectively $\mathrm{NHO}_{3}$ and acetate ammonium buffer with $\mathrm{pH}=4.8$ ). The essence of the atomic absorption method of analysis was based on the measurement of light absorption by free metal atoms, which occurs when light passes through a layer of atomic vapor in a graphite furnace of an atomic absorption spectrometer. The metal content is determined by the value of the integral analytical signal and is calculated according to a pre-established calibration dependence (Khabarova, 2017).

\section{RESULTS AND DISCUSSION}

The maximum of surface concentrations of pollutants in the area of the power plant shifts to the west and is localized on the macroscline of the Central Russian Upland in 7-8 km from the station. The share of western winds in comparison with the earth's surface increases by $7 \%$ at an altitude of $300 \mathrm{~m}$. The process of dispersion of technogenic impurities is influenced by the inversion of the surface atmosphere. On average, 4 cyclones per month replace each other and are accompanied by south-westerly winds. The main part of all elevated inversions in the year is associated with cyclones. During the anti-cyclone regime, there are winter adventitious ones associated with the entry of air masses from the Arctic and intensive surface cooling at night and summer radiation elevated inversions. The annual natural inversion on average for the year in the layer is $0.01-0.5 \mathrm{~km}$

Table 1: Average content of heavy metals in the main parent rocks of Ryazan region, $\mathrm{mg} / \mathrm{kg}$.

\begin{tabular}{lcccc}
\hline Soil & $\mathrm{Cu}$ & $\mathrm{Zn}$ & $\mathrm{Pb}$ & $\mathrm{Cd}$ \\
\hline Forest loam & 24 & 48 & 10 & 0.16 \\
Fluvioglacial sand & 0.6 & 4 & 2 & 0.05 \\
\hline
\end{tabular}

is observed in $22 \%$ of cases of observation and in January - in $41 \%$ and in July-in $11 \%$ of cases. Therefore, in winter, the conditions for the dispersion of emissions are not favorable and their localization occurs.

The dispersion of impurities is also influenced by surface inversions, which can often be observed in the summer months in the early morning and in the spring when anticyclones change. Surface inversions reach the greatest intensity before sunrise, elevated ones-shortly after sunrise; they collapse during the day. In the winter months, due to the homogeneous surface of adventitive and non-radiative factors, the daily course of the recurrence of inversion is very poorly expressed, while the occurrence of these factors is the maximum for the whole year.

Ryazan GRES is the sixth in the list of the most powerful thermal power plants of the Russian Federation (Fig 1).

The natural conditions of the area where RGRES is located are typical for broad-leaved forest and forest-steppe landscapes, which largely determine the behaviour of technogenic toxicants (Tables 1, 2).

According to the data in Fig 2, the weather conditions during the research period varied greatly.

The relief marginal escarpment is well pronounced. It has a steepness of about $7-8^{\circ}$ and a height of about $50 \mathrm{~m}$. It is this slope that accumulates the maximum concentration of pollutants from GRES. The eastern part of the GRES impact zone is located on the Oka-Don Plain. Phytogeochemical examination was carried out in the zone of five rings from the pipe:

First ring - $\mathrm{R} 1$ is $500 \mathrm{~m}$.

Second ring - $\mathrm{R} 2$ is $2.5 \mathrm{~km}$.

Third ring - R3 is $7 \mathrm{~km}$.

Fourth ring - R4 is $15 \mathrm{~km}$.

Fifth ring - R5 is $30 \mathrm{~km}$.

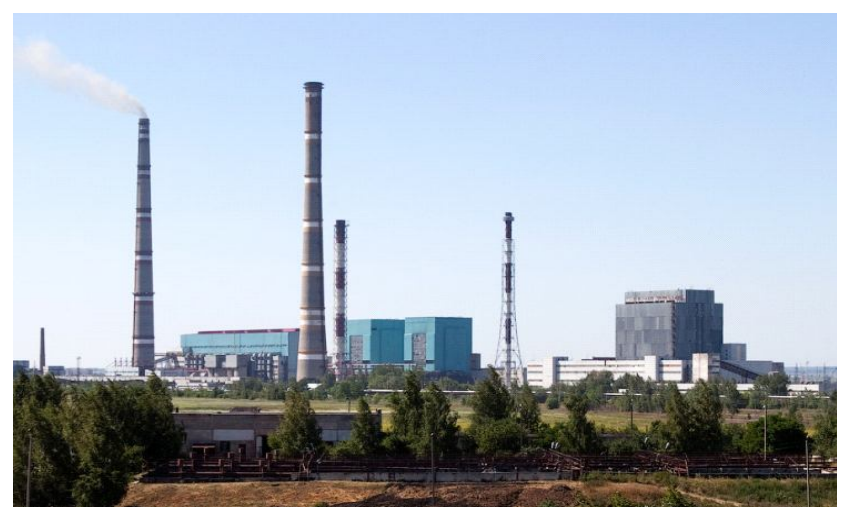

Fig 1: View of the Ryazan GRES.

Table 2: Average content $(\mathrm{mg} / \mathrm{kg})$ and degree of mobility (\%) of heavy metals in the arable horizon of soil types in Ryazan region.

\begin{tabular}{|c|c|c|c|c|c|c|c|c|}
\hline \multirow{2}{*}{ Soil } & \multicolumn{4}{|c|}{ Gross content } & \multicolumn{4}{|c|}{ Degree of mobility } \\
\hline & $\mathrm{Cu}$ & $\mathrm{Zn}$ & $\mathrm{Pb}$ & $\mathrm{Cd}$ & $\mathrm{Cu}$ & $\mathrm{Zn}$ & $\mathrm{Pb}$ & $\mathrm{Cd}$ \\
\hline Chernozemic soil & 40 & 67 & 15 & 0.20 & 0.2 & 2.0 & 2.7 & 15.0 \\
\hline Gray forest & 43 & 65 & 21 & 0.19 & 0.5 & 2.7 & 2.2 & 15.8 \\
\hline Sod-podzolic & 2.7 & 17 & 7 & 0.05 & 5.4 & 8.8 & 4.2 & 68 \\
\hline
\end{tabular}




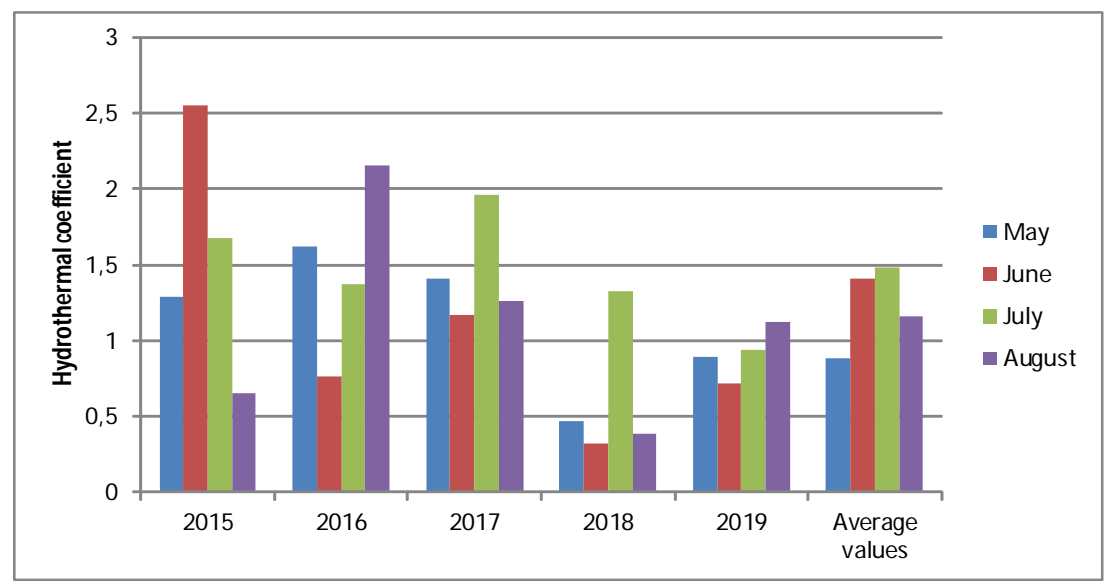

Fig 2: The values of the SCC for the period of research.

Table 3: The content of mobile forms of metals in the soils of the zone, depending on the main directions of the RGRES impact.

\begin{tabular}{llccc}
\hline Principle & Direction & Distance, $\mathrm{km}$ & Total pollution indicator & Excess by element of background content \\
\hline $\mathrm{Mn}$ & North & 15 & 2.16 & 2 times \\
$\mathrm{Cd}$ & North & 2.5 & 3.33 & 3.3 times \\
$\mathrm{Cr}$ & East & 7 & 2.0 & 2 times \\
$\mathrm{Cd}$ & Southeast & 15 & 2.0 & 2 times \\
$\mathrm{Pb}$ & Southeast & 2.5 & 4.32 & 4.3 times \\
$\mathrm{Cd}$ & Southeast & 7 & 2.2 & 2.2 times \\
$\mathrm{Cr}$ & Southeast & 7 & 2.8 & 2.8 times \\
$\mathrm{Mn}$ & Southeast & 15 & 2.0 & 2 times \\
$\mathrm{Cd}$ & South & 15 & 2.2 & 2.2 times \\
$\mathrm{Co}$ & Southwest & 30 & 2.3 & 2.3 times \\
$\mathrm{Zn}$ & Southwest & 2.5 & 8.53 & 8.53 times \\
$\mathrm{Cr}$ & West & 7 & 2.9 & 2.9 times \\
$\mathrm{Zn}$ & Northwest & 15 & 3.9 & 3.9 times \\
\hline
\end{tabular}

Brown coal and fuel oil are the main types of fuel for RGRES. In winter months, more than $80 \%$ of the fuel comes from brown coal. Only fly ash is captured in the exhaust gases of Ryazan GRES. The efficiency of cleaning emissions at Ryazan GRES (design is $99.4 \%$, actual is about $97.5 \%$ ) is higher than the average for the Russian energy sector $(94.5 \%)$.

The results of the study of the content of acid-soluble forms of heavy metals are presented in Table 3. Categories of soil pollution were also considered on the basis of TPI.

Analyzing the data in Table 3, it is possible to conclude that the greatest distribution of mobile forms of heavy metals is observed in the southern, southeastern directions in radii from $2.5 \mathrm{~km}$ to $30 \mathrm{~km}$; in the southwest direction in radii from $500 \mathrm{~m}$ to $7 \mathrm{~km}$; in the northern and northwestern directions in radii of $500 \mathrm{~m}$ to $2.5 \mathrm{~km}$ from the station.

Due to the large area of farmland, mainly cultivated vegetation was studied, among which cereals predominated. Communities of floodplain meadows and forest belts were studied, in the samples of which the ratio of species was observed.

Analyzing the data obtained, the following conclusions can be drawn:
- The following plant species grow in all zones (1-5 rings): common tansy, medicinal dandelion, creeping wheatgrass, common wormwood, barnyard grass;

- As the distance from the "pipe" increases, the species composition of plants expands. In addition to the plants listed in the first paragraph, the following plants grow in the $R=$ $500 \mathrm{~m}$ zone: clover, alfalfa, thistle, geum, spurge, burmarigold and horsetail. One can find in the northeastern part of in ring 2 cruciferous plants and in the rest area the same plants as in ring 1 . In ring 3 there are more: alfalfa, horse sorrel, burdock, bindweed and motherwort. Orne can find in ring 4 alfalfa, cow parsnip, chicory, yarrow, thistle, burdock, horse sorrel and among trees there are maple and oak. In ring 5 one can find burdock, sorrel, meadow geranium, stinging nettle, St. John's wort, yellow alfalfa and motherwort.

The increased bio absorption of zinc and cadmium is primarily due to the bio-friendliness of zinc and the high availability of readily mobile cadmium for plants. Plants absorb these elements with little or no resistance. The minimum level of $\mathrm{Cu}$ accumulation is associated with a deficiency of mobile forms and that of $\mathrm{Pb}$ with its toxicity. 
Table 4: The content of heavy metals in the biomass of the main species of plant communities in the zone of influence of RGRES, mg/ $\mathrm{kg}$ of air-dry matter.

\begin{tabular}{|c|c|c|c|c|c|c|c|c|}
\hline \multirow{3}{*}{ Biomass } & \multirow{3}{*}{$\frac{\mathrm{Cu}}{\frac{\min -\max }{\mathrm{X}}}$} & \multicolumn{3}{|c|}{$\mathrm{Zn}$} & \multirow{3}{*}{$\frac{\mathrm{Pb}}{\frac{\min -\max }{\mathrm{X}}}$} & \multicolumn{3}{|c|}{$\mathrm{Cd}$} \\
\hline & & $\mathrm{V}, \%$ & $\min -\max$ & $\mathrm{V}, \%$ & & $\mathrm{~V}, \%$ & $\min -\max$ & $\mathrm{V}, \%$ \\
\hline & & & $x$ & & & & $x$ & \\
\hline Wheat: & $0.7-2.1$ & 43.4 & $6.4-21.4$ & 51.2 & $0.05-1.26$ & 50.1 & $0.031-0.07$ & 27.4 \\
\hline Straw & $0.9-5.5$ & & $8.46-24.4$ & & 0.71 & & $0.014-0.05$ & \\
\hline Grain & 3.16 & & 21.8 & & $0.22-0.52$ & & 0.03 & \\
\hline Oats: & $1.2-1.8$ & 18.1 & $7.4-12.5$ & 18.2 & $0.31-1.46$ & 66.2 & $0.021-0.100$ & 61.1 \\
\hline Straw & $1.7-3.4$ & & $23.0-35.8$ & & $0.26-0.44$ & & $0.020-0.030$ & \\
\hline Grain & 2.62 & & 26.36 & & 0.37 & & 0.027 & \\
\hline Barley: & $0.8-2.9$ & 53.2 & $8.8-30.1$ & 49.2 & $0.54-0.98$ & 25.5 & $0.036-0.100$ & 29.3 \\
\hline Straw & $2.3-4.3$ & & $26.3-39.6$ & & $0.19-0.44$ & & $0.025-0.070$ & \\
\hline Grain & 3.73 & & 32.64 & & 0.34 & & 0.046 & \\
\hline Rye: & $0.8-1.1$ & 16.4 & $9.1-12.6$ & 16.1 & $0.81-0.97$ & 9.9 & $0.041-0.060$ & 33.6 \\
\hline Straw & $1.5-4.1$ & & $36.0-44.6$ & & $0.18-1.11$ & & $0.015-0.060$ & \\
\hline Grain & 3.21 & & 40.6 & & 0.57 & & 0.035 & \\
\hline \multirow[t]{2}{*}{ Corn : Grain } & $1.9-8.0$ & 48.0 & $12.0-33.8$ & 30.0 & $0.45-21.6$ & 41.1 & $0.045-0.16$ & 46.0 \\
\hline & 4.15 & & 20.75 & & 1.09 & & 0.095 & \\
\hline \multirow[t]{2}{*}{ Clover : Herbage } & 4.9-11.1 & 35.0 & $18.6-27.5$ & 16.0 & $0.72-1.64$ & 26.1 & $0.032-1.140$ & 43.0 \\
\hline & 6.57 & & 23.22 & & 1.27 & & 0.088 & \\
\hline \multirow[t]{2}{*}{ Sunflower : grain } & $10.0-17.9$ & 54.0 & $32.1-44.1$ & 16.0 & $1.76-3.78$ & 36.0 & $0.184-0.28$ & 11.1 \\
\hline & 11.26 & & 38.4 & & 2.97 & & 0.224 & \\
\hline
\end{tabular}

The variation in the values increases with a decrease in the concentration of soil elements in the phytomass, reaching maximum for $\mathrm{Cd}$, which reflects the known regularities. The absorption of heavy metals by plants of various taxonomic groups is specific. In particular, the biological and chemical characteristics of cereals determined the minimum intensity of their accumulation of all heavy metals. In this case, bio-friendly $\mathrm{Zn}$ and $\mathrm{Cu}$ are predominantly accumulated in the generative and storage organs of cereals - caryopses, while the penetration of toxicants $(\mathrm{Pb}$ and $\mathrm{Cd})$ there is blocked.

However, it should be recognized that, in comparison with $\mathrm{Pb}$, even $\mathrm{Cu}$ and $\mathrm{Cd}$ still have a fairly high availability for cereals, despite the presence of effective barrier mechanisms. A similar ratio of the accumulation of heavy metals in vegetative storage organs with a high availability of $\mathrm{Cd}$ is also revealed for fodder beets.

Concentrators of metals in the study area include wild plants - coenomorphs of selvants (forest grasses), growing in conditions of low $\mathrm{pH}$ values of the soil and a high level of mobile forms of heavy metals; agricultural crops sunflower, buckwheat; and according to $\mathrm{Cd}$ - fodder root crops (Table 4).

According to our data, there is no excess level of excessive accumulation of heavy metals in the phytomass of the studied agricultural landscapes.

Therefore, the accumulated heavy metals at the moment do not pose a danger to plants and cannot have a

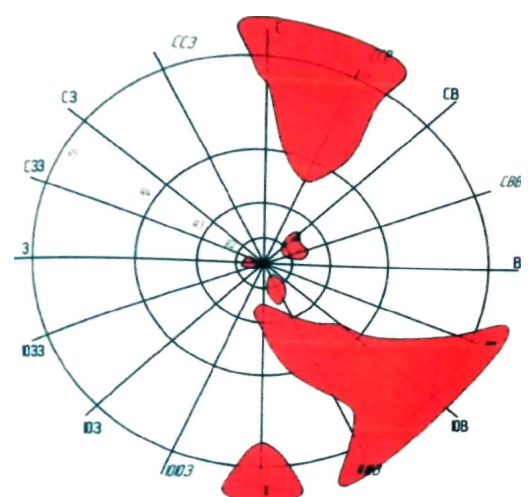

Fig 3: Interpolation fields (metal shapes-excess zone).

negative impact on the formation of the crop. But for farm animals, this level of heavy metals has a negative impact, which in turn can affect humans. Maps of the isolines of the distribution of heavy metals along the belts are shown in Fig 3.

Table 4 shows that heavy metals in plant biomass as a whole correspond to the norm in the regions of the foreststeppe zone. In a number of cases, there is a deficit in the accumulation of $\mathrm{Cu}$, less often $\mathrm{Zn}$ (especially in cereal straw), often below the optimal level, while the $\mathrm{Pb}$ concentration is relatively exceeded (by $18.1 \%$ ). The excess of $\mathrm{Pb}$ MPC for grain and legumes is sometimes observed in background conditions. 
According to the data, no excess of the level of excessive accumulation of heavy metals in the phytomass of the studied agricultural lands is observed.

As a recommendation, the use of lime materials and fertilizers is suggested, that allows:

- To bring the reaction of the environment to a neutral level, when the mobile compounds of HMs and other, other toxicants pass into a form that is inaccessible or less accessible to plants.

- To create in the solution a concentration of antagonistic principles (potassium, phosphorus, calcium and others), which in turn will lead to a decrease in the level of toxic elements in crops.

- To convert toxic compounds to less toxic forms.

\section{CONCLUSION}

As a result of studies conducted on the territory of the western part of the Ryazan region, which is located in the zone of influence of the RGRES, it was found out that the degree of contamination of agricultural land of this section of the farm with heavy metals is moderately dangerous.

Thus, the greatest distribution of mobile forms of heavy metals in the zone of influence of RGRES is observed in the southern and south-eastern directions in radii from 2.5 $\mathrm{km}$ to $30 \mathrm{~km}$ in the south-western direction in radii from 500 $\mathrm{m}$ to $7 \mathrm{~km}$, in the northern and north-western directions in radii of $500 \mathrm{~m}$ to $2.5 \mathrm{~km}$ from the station. Particles of fly ash in emissions have a diameter of less than 10 microns, which determines their significant stay in the air and a significant concentration of heavy metals, primarily $\mathrm{Zn}$ and $\mathrm{Pb}$.

The following plant species grew in all zones of the five rings of the sampling pipe: common tansy, medicinal dandelion, creeping wheatgrass, wormwood and barnyard grass. As the pollutant is removed, the species composition of plants expands and starting from the $R=500$ zone, the species diversity is maximum.

In the area of anthropogenic impact, the content of heavy metals in the biomass of agricultural plants was generally in line with the norm. In some cases, there was a deficit in the accumulation of $\mathrm{Cu}$, less often $\mathrm{Zn}$, primarily in cereal straw, while the concentration of $\mathrm{Pb}$ was relatively increased (by $18.1 \%$ ). The excess of $\mathrm{Pb}$ MPC for grain and legumes was also observed in background conditions.

It is recommended to use measures that reduce the content of heavy metals, including plowing with seam turnover, minimal tillage (agrotechnical), the use of Ca-Sr, $\mathrm{K}-\mathrm{Cs}$ antagonist ions (agrochemical), phyto melioration, bioremediation, cultivation of tolerant varieties and crops (biological).

The transformation and improvement of agricultural landscapes located in the zone of influence of the Ryazan GRES, with the help of various environmental measures, will increase the ecological stability of lands, protect the fertility of soils and the quality of underground and surface water, contributes to the production of high-quality agricultural products, ensures the closure of the biological cycle of heavy metals and reduce economic damage from land pollution.

\section{REFERENCES}

Aleminew, À., Alemayehu, M. (2020) Soil fertility depletion and its management options under crop production perspectives in Ethiopia. Agricultural Reviews. 41: 91-105.

Bhabesh, G. (2011). Soil properties and nutrients availability as affected by integrated nutrient management after rainfed cropping sequence. Indian Journal of Agricultural Research. 45(4): 346-349.

Butov, A., Zakharov, V. and Zubkova, T. (2019). Biological quality and preservation of potato under drip irrigation and different fertilizers. Bulgarian Journal of Agricultural Science. 25(2): 37-44.

Dias, T., Dukes, A.M. and Antunes, P. (2015). Accounting for soil biotic effects on soil health and crop productivity in the design of crop rotations. Science of Food and Agricultural. 95(3): 447-454.

Díaz Zorita, M., Perfect, E., Grove, J.H. (2002). Disruptive methods for assessing soil structure. Soil and Tillage Research. 64: 3-22.

Gregorich, E.G., Carter, M.R., Doran, J. W., Pankhurst, C.E. and Dwyer, L.M. (1997). Chapter 4 Biological attributes of soil quality. Developments in Soil Science. Elsevier. 25: 81-113.

Grimm, N.B., Grove, J.G., Pickett, S.T.A. and Redman, C.L. (2000). Integrated approaches to long-term studies of urban ecological systems: Urban ecological systems present multiple challenges to ecologists-pervasive human impact and extreme heterogeneity of cities and the need to integrate social and ecological approaches, concepts and theory. BioScience. 50 (7): 571-584.

Gulidova, V.A., Zubkova, T.V., Kravchenko, V.A. and Dubrovina, O.A. (2017). The dependence of photosynthetic indices and the yield of spring rape on foliar ferttilization with microfertilizers. OnLine Journal of Biological Sciences. 17(4): 404-407.

Ivanisova, N.V. Kurinskay, L V., Kolesnikov, S.I. and Davydenko, N.M. (2019). Influence of the degree of anthropogenization of landscapes on changes in soil factors. International Multidisciplinary Scientific GeoConference: SGEM; Sofia. 19(3.2).

Khabarova, T.V. (2017). Practicum. Methods of ecological research. Ryazan. 128.

Lambers, H., Mougel, C. and Jaillard, B. et al. (2009). Plantmicrobe-soil interactions in the rhizosphere: An evolutionary perspective. Plant Soil. 321: 83-115.

Marfenina, O.E. Ivanova, A.E. Kislova, E.E. and Sacharov, D.S. (2008). The mycological properties of medieval culture layers as a form of soil 'biological memory' about urbanization. J Soils Sediments. 8: 340-348.

Musayev, F., Danilin, S., Zakharova, O. and Rodikov, S. (2020). Agroecological role of biohumus on sod-podzolic soil during irrigation of the rump-timothy grass mixture. E3S Web of Conferences. 210: 04003.

Navneet, K., (2014). Impact of intensive agriculture on natural resource base of Punjab - A review. Agricultural Reviews. 35: $279-286$. 
Otterpohl, R., Albold, A. and Oldenburg, M. (1999). Source control in urban sanitation and waste management: Ten systems with reuse of resources. Water Science and Technology. 39(5): 153-160.

Pavao Zuckerman, M.A. (2008). The Nature of Urban Soils and Their Role in Ecological Restoration in Cities. Restoration Ecology. 16(4): 642-649.

Rillig, M.C. and Mummey, D.L. (2006). Mycorrhizas and soil structure. New Phytologist. 171(1): 41-53.

Shchur, A.V. (2017). Influence of biologically active preparations on caesium-137 transition to plants from soil on the territories contaminated after Chernobyl accident. Impact of Cesium on Plants and the Environment. Switzerland. $51-70$.

Targulian, V.O. and Bronnikova, M.A. (2019). Soil Memory: Theoretical Basics of the Concept, Its Current State and Prospects for Development. Eurasian Soil Sc. 52: 229243.

Vinogradov, D., Lupova, E., Khromtsev, D. and Vasileva, V. (2018). The influence of bio-stimulants on productivity of coriander in the non-chernozem zone of Russia. Bulgarian Journal of Agricultural Science. 24(6): 1078-1084.

Vinogradov, D.V., Byshov, N.V., Evtishina, E.V., Lupova, E.I., Tunikov, G.l. and Morozova, N. I. (2018). Peculiarities of growing gold-of-pleasure for oilseeds and its use in feed production in the non-chernozem zone of Russia. Àmazonia Investiga. Ñolombia. 7(16): 37-45.
Vinogradov, D.V., Makarova, Ì. P. and Kryuchkov, ì.ì. (2021). The use of mineral fertilizers in sunflower crops in the conditions of Ryazan region. IOP Conf. Series: Earth and Environmental Science. 624: 012077.

Vinogradov, D.V., Stenichkina, M.Y. and Vasileva, V. M. (2020). Increasing the oats (Avena sativa) productivity when couse of fertilizers and growth regulator in conditions of the nonchernozem zone of Russia. International Transaction Journal of Engineering, Management and Applied Sciences and Technologies. 11(10).

Vinogradov, D.V., Vasileva, V.M., Makarova, M.P., Kochurov, B.I. and Lupova, E.I. (2019). Agroecological effect of sewage sludge and its mixtures with zeolite on the agrocenoses of oilseeds. Theoretical and Applied Ecology. 3: 122-128.

Vos, P. Meelis, E. and Ter Keurs, W.J. (2000). A Framework for the Design of Ecological Monitoring Programs as a Tool for Environmental and Nature Management. Environmental Monitoring and Assessment. 61: 317-344.

Zubkova, T.V., Motyleva, S.M. and Dubrovina, O.A. (2020). The study of rape seed plants development in the rosette phase in the face of organic fertilizers and natural zeolite. Ecology, Environment and Conservation. 26(1): 465-470. 